\title{
THE INFLUENCE OF LINGUISTIC INTELLIGENCE AND PARENT'S ROLE TOWARD ENGLISH ACHIEVEMENT AT PRIVATE SENIOR HIGH SCHOOL IN DEPOK
}

\author{
Mu'thia Mubasyira \\ Program of English Education, Faculty of Language and Art, University of Indraprasta PGRI \\ Jalan Nangka No. 58C Tanjung Barat, Jagakarsa, South Jakarta 12530 \\ muthia.mubasyira@yahoo.com
}

\begin{abstract}
This research aims at knowing the influence of linguistic intelligence and parent's role towards English achievement at private senior high school in Depok. The data for linguistic intelligence is taken from worksheet through test, meanwhile the data for parent's role is taken from questionnaire. Then the data for English achievement is taken from the score of English in students' academic record which is familiar called rapor. Data analysis shows coefficient correlation $(\mathrm{R})=0,742$ and determination coefficient is $55,1 \%$. It means that there are significant and strong influence of linguistic intelligence and parent's role towards English achievement. English is influenced by linguistic intelligence and parent's role for $55,1 \%$. Meanwhile, the rest $44,9 \%$ is influenced by other factors. The hypotheses test through regression analysis results regression equality $\mathrm{Y}=44,93+1,050 \mathrm{X}_{1}+0,251 \mathrm{X}_{2}$. The result for regression equality significant test is of $\mathrm{Sig}=0,000$ and $\mathrm{F}_{\text {observed }}=53,389$ so Sig score $<0,05$ And $\mathrm{F}_{\text {observed }}>\mathrm{F}_{\text {table }}$ so $\mathrm{H}_{\mathrm{o}}$ is rejected and $\mathrm{H}_{1}$ is accepted. It means that regression coefficient is significant. In conclusion, there are strong and significant influence of linguistic intelligence and parent's role towards English achievement at private senior high school in Depok.
\end{abstract}

Key words: linguistic intelligence, parent's role, English achievement

\begin{abstract}
ABSTRAK
Tujuan penelitian ini adalah untuk mengetahui pengaruh kecerdasan berbahasa dan peran orangtua terhadap prestasi matapelajaran Bahasa Inggris SMA swasta di Kota Depok, Jawa Barat. Data tentang kecerdasan berbahasa diperoleh dengan menggunakan tes dan data tentang peran orangtua digunakan angket sebagai instrumen penelitian yang sebelumnya telah diuji tingkat validitas dan reliabilitas. Sedangkan data untuk prestasi belajar diperoleh dari nilai rapor semester ganjil 2012/2013 untuk mata pelajaran bahasa Inggris. Hasil analisis diperoleh nilai koefisien korelasi $(R)=0,742$ dan Koefisien Determinasi sebesar 55,1\% artinya terdapat pengaruh yang kuat antara kecerdasan berbahasa dan peran orangtua terhadap prestasi belajar matapelajaran Bahasa Inggris SMA di Kota Depok Jawa Barat. Dan prestasi belajar bahasa Inggris dipengaruhi sebesar 55,1\% oleh kecerdasan berbahasa dan peran orangtua sedangkan sisanya 44,9\% ditentukan oleh faktor lain. Sedangkan pengujian hipotesis melalui analisis regresi diperoleh persamaan $Y=44,93+1,050 X_{1}+0,251 X_{2}$. Hasil uji signifikansi persamaan regresi diperoleh nilai Sig $=0,000$ dan $F_{\text {hitung }}=53,389$ maka nilai Sig < 0,05 dan $F_{\text {hitung }}>F_{\text {tabel }}$ maka $H_{0}$ ditolak dan $H_{1}$ diterima yang artinya koefisien regresi tersebut signifikan. Kesimpulannya adalah terdapat pengaruh yang kuat dan signifikan antara kecerdasan berbahasa dan peran orangtua terhadap prestasi belajar Bahasa Inggris SMA di Kota Depok.
\end{abstract}

Kata kunci: kecerdasan berbahasa, peran orang tua, prestasi belajar. 


\section{INTRODUCTION}

According to UNESCO, human being consists of mind or thought dimension, spirit or soul dimension, body or physical dimension and emotional dimension. These four dimensions will create a human being as a whole person who will always live together in harmony. Therefore, we do need language as a mean of communication. Many teories regarding language have been explained by a lot of experts. One of them is based on Encarta Encyclopedia which mention that "Language involves specialized cortical regions in a complex interaction that allows the brain to comprehend and communicate abstract ideas. The right brain and left brain have their own function".

Formal education ought to recognise the potential of every students' and educate them to achive the goal of education law, 2003 in order to make them ready to face the globalization era. In this era, education especially formal education in Indonesia controls essential aspect in raising the childres not only to be well-educated ones but also to have a polite attitude and mature character. The function and goal of national education can be reflected to the system used to achieve these targets especially to recognize the potential of the students by knowing the the tendency of intelligence they have.

The learning process is not able to be hampered just because of the age. One proverb said that never too old to learn. Meaning that the process of learning always happens as long as the human alive therefore it is essensial to increase the tendency of intelligence within their them selves especially for the productive age. In other words, intelligence is a significant factor of human life. Gardner in Richards and Rodgers (2001) said that "Intelligence is a bio-psychological potential to process information that can be activated in cultural setting to solve problems or to create product that are valuable in cultural setting."

The importance of language is cleanly proven. Without language their will be no communication at all. There are four basic skills in language named listening, reading, speaking and writing. These skills will be combined with the aspects in language which consists of pronounciation, vocabulary and grammar. Formal education through teachers will facilitate the students to recognize their tendency of intelligences either logical/mathematical, linguistics, spatial, musical, bodily/kinesthetic, interpersonal, intrapersonal, naturalistics, or existential. Recognizing the potency of the students will guide them to achieve the proper profession later on. The earliest both teachers and parents know it, the easier the exact methods to help them develop their potencies.

Among these divisions of intelligences which has been explained above, linguistic intelligence which has something to do with words either spoken or written is being discussed in this research. The students who has the tendency to the linguistics has the potency to be come news reader, story teller, speaker, orator, editor, and journalist. Therefore this paper is focusing to analyse the influence of linguistic intelligence and parents' role towards English achievement in private seniour high school in Depok.

These are the definitions of learning according to several experts. Gagne in Dahar (2011:2) explains that "Learning can be stated as a process where an organization change its manner after following certain experiences". It needs several period of time to know the result of the change 
and whether the goal of this process is already achieved by the students.

According to Kimble in Prawira (2012:227), "Learning is a relative permanent changes in manner behaviour happened to every person as the result of several practice and exercise which are supported by a reward". The people who join the learning process is required not to go back to their old manner since they have faced certain treatment of learning.

Therefore, it can be concluded that learning is the main activity in the whole process of education. It means that the achievement of educational goal depends on how the students experience the learning process. Generally, learning can be defined as the activity to obtain the knowledge. A student has been faced a learning process after knowing something new.

There are several definitions of achievement. In Kamus Besar Bahasa Indonesia (2007:895), “Achievement can be defined as the result of certain activities done by somebody". Meanwhile Djamarah in Dhien (20011:1) states that "Achievement is one part of the result done by individual or society". The positive result of learning process can be showed through the achievement made the students.

Futhermore, Tohirin (2005:140) told that "Achievement is something got by the students after doing learning activity". Then Astuti (2008:12) said that "Achievement is the result showed by the students after having certain level of education and training with some changes in values and manner". The achievement must have some valueable changes reflected through good manner.

Learning achievement consists of cognitive domain, afective domain and psychomotor domain. To get a satisfied achievement, there are two factors noticed according to Suryabrata
(1998:233) in Winkel which are called internal factors and external factors. Internal factor can be defined as the entire factors within an individual divided into physiology which relates to the health and the senses of the students and psychology which deals with intellegence, manner and motivation. Meanwhile, the external factor of learning achievement is all factors surrounding the students consist of: 1) family. It deals with financial condition, educational background and parent's role; 2) school. It is connected by the learning facility, teachers' competence, curricullum and learning methods; and 3) society. It is affected by socioculture and participation to the education itself. After examining these arguments, it can be concluded that achievement is the result of studying in form of competence, skills and manner after interacting with learning activities in certain period of time.

According to Worrel and Stilwell in Budiarto, et. al. (2004), parents' role can be defined as the cognitif strategy of four factors named problem orientation, problem survey, relevant focus and irrelevant stimuli. Moreover, the attention can be formulated into the focus of learning object consiously and uncounsiously done through several activities.

Intensive attention is the fully care to the object of learning. Dealing to this idea, Sadirman (2001:43) states that "Attention is about the concious intensity followed by the process of learning". This argument is supported by Bandura in Syah (2011:112) that "An attention is the primary step in the process of learning". In this stage, the students generally focus the attention to the role model because of the uniqueness compared with the manner known before. Meanwhile unintensive attention is the care that have not shared 
to the object of learning. However, the students also need such kind of attention to make them feel comfortable. After examining those opinions, it can be concluded that role is the spot of psicological intensity or conciousness followed through certain activities.

Family is the first environment where the children get the guide and education as they spend most of their times in their family. In the other word, their education achieved by the children is environment (Sabri, 1999:15-16). After knowing the inner environment, the children also have to know the outer environment in order to give a great influence to the next children's lives. Therefore, the role of family especially parents can not be neglected.

Meanwhile Fuller (2010) said that learning starts from home. Parents are the primary educator from their children. Since the parents themselves are the first one who educate the children from the earliest scope of education. Thus, Watson in Hidayati (1999:7) explains that the "Environment where the child stay plays a significant influence to his/her growth". Futhermore, Hidayati (1999:7) argued that:

"It is clear that parents take the responsibility for their children. Only with the limitation of their parents' financial, other people should help by building educational institution to teach knowledge and competent."

Moreover, Djamarah (2004:29) argued that "Parents' role is the starting point for their children education". Children experience the first thing valuable for their life from their parents and the parents have an obligation to give their children how to behave well with good manner. It is supported by Slameto (2003:63-64) who explains that "The atmosphere of family affect children achievement". If the atmosphere of family support their learning activities, it will bring satisfied result but if the atmosphere is not condusive, the good result is not warranted.

The parents' role can be expressed in form of family picnic as what Benyamin (2010:3) stated:

"So many values can be got by having family picnic. Children are able to have sport in many activities in order to increase their individual's ability such as having a good relation with others. Creativities are able to develop with many ways to inrtoduce something new so that the characters' of their children can be built."

Based on the above explanation, it can be concluded that parents' role is the entire activities done to motivate the children to enhance their competence to reach the optimal achievement.

An expert named Binet explained that intelligence is the ability to state and maintain certain aims in order to have adjustment to achive that goals and aims and to have an introspection to we our selves. The introspection will gain success not only using the brain but also the heart. How the heart takes control to develop the brain function to overcome every problem faced is defined as the intelligence.

Psychometric theories are based on a model that portrays intelligence as a composite of abilities measured by mental tests. This model can be quantified. For example, performance on a number-series test might represent a weighted composite of number, reasoning, and memory abilities for a complex series. Mathematical models allow for weakness in one area to be offset by strong ability in another area of test performance. In this way, 
superior ability in reasoning can compensate for a deficiency in number ability. This teory is supported by Charles Edward Spearman.

Cognitive theory, moreover argued that Instead of starting with conventional psychometric tests, the experts who support the teory began with tasks that experimental psychologists were using in their laboratories to study the basic phenomena of cognition, such as perception, learning, and memory. This theory is supported by Earl B. Hunt, Nancy Frost, and Clifford E. Lunneborg.

Meanwhile, cognitive-contextual theories deal with the way that cognitive processes operate in various settings. Two of the major theories of this type are that of the American psychologist Howard Gardner and that of Sternberg. In 1983 Gardner challenged the assumption of a single intelligence by proposing a theory of "multiple intelligences." Earlier theorists had gone so far as to contend that intelligence comprises multiple abilities. But Gardner went one step farther, arguing that intelligences are multiple and include, at a minimum, linguistic, logical-mathematical, spatial, musical, bodily-kinesthetic, interpersonal, and intrapersonal intelligence.

The biological theories discussed above seek to understand intelligence in terms of hypothetical mental constructs, whether they are factors, cognitive processes, or cognitive processes in interaction with context. Biological theories represent a radically different approach that dispenses with mental constructs altogether. Advocates of such theories, usually called reductionists, believe that a true understanding of intelligence is possible only by identifying its biological basis.
Based on the explaination above regarding intelligence, linguistic intelligence can be considered to the one of multiple intelligence required by cognitive-contextual theory. As this research focuses to the recognization of potencies of the students who have the tendency to the linguistic intelligence most than other kind of intelligence facilitating by formal institution and supporting by parents' to guide their children achive the proper score in English achivement and finding the proper profession after graduating from formal education.

Gardner in Richards and Rodgers (2001:116) argued that "Linguistic intelligence is one of the intelligences that human being have". Linguistic intelligence is the ability to use language in special and creative ways which is something lawyers, writers, editors and interpreters are strong in.

Catur (2010) argued that linguistic intelligence included the ability of someone to use language and words orally and written in different form to express the ideas. Children with high linguistic intelligence generally are signed by the pleasure to the activity deals with the usage of language such as reading, written the composition, writting poem and so on.

Linguistic intelligence refers to an enhanced ability of an individual to use one or several languages to convey spoken or written communications to others. In daily life, many people demonstrate linguistic intelligence through both introverted and extroverted activities. The person with the tendency of linguistic intelligence also balances the whole existence on the foundation of language either oral, written or non verbal.

Since the potency of students with linguistic intelligence are suggested to be news readers, story teller, speaker, 
orator, editor and journalist. Meanwhile, the skills and aspects of language especially English can not also be ignored, the measurement to recognize such kind of potency will be through answering the language testing made by the researcher.

\section{METHOD}

The research was conducted in the private senior high school in Depok. Depok itself is a city located in westjava province, Indonesia. It has 11 sub districts namely Beji, Pancoran Mas, Cipayung, Sukmajaya, Cilodong, Limo, Cinere, Cimanggis, Tapos, Sawangan, and Bojong Sari. Out of 11 sub districts, two districts choosen randomly. To be more focus on conducting the research, the school with the same accreditation A represents each sub district. The three schools which will be observed namely SMA Yapan Indonesia from Sawangan sub district, SMA Sejahtera from Pancoran Mas sub district and SMA Tugu Ibu from Sukmajaya sub district.

This study emphasizes on the influence of linguistic intelligence and parents' role toward English achievement. It means there are two independent variables and one dependent variable; variable $\mathrm{X}_{1}$ as the first independent variables namely linguistic intelligence and variable $\mathrm{X}_{2}$ as the second independent variables that is parents' role which have interconnected and influenced the variable $\mathrm{Y}$ as the dependent variable named English achievement. The method used is a survey with multicorrelation technique.

There are two ways of collecting the data, library and field research. In the library research, the resarchers read and used any reference books, articles, encyclopedy and website as many as possible dealing with the topic of discussion. Meanwhile, in the field research, the researcher conducted a survey research at private senior high school grade ten in Depok by collecting data both questionare and worksheet.

There are two kinds of variables, namely independent variable and dependent variable. The independent variables therefore in this research are linguistic intelligence and parents' role. Meanwhile, the dependent variable is English achievement.

\section{RESULTS AND DISCUSSION The Data of Linguistic Intelligence}

The data regarding linguistic intelligence taken from giving a test through worksheet. The test is used multiple choice consist of 25 questions which has been valid and reliable. Linguistic intelligence statistics is known from 90 respondents which the minimum score is 7 and the maximum score is 19. Meanwhile, the average of all scores in the data set (mean) for Linguistic Intelligence is 13,30 , the most frequently score in the data set (mode) is 13 and the score at centre of distribution (median) is 13,33. Moreover, the score which shows standard deviation is 3,15677 and the variance is 9,965 .

Linguistic Intelligence Frequency above is taken from 90 respondents with the minimum score is 7 for 2 students or $2,2 \%$ of the entire respondents and the maximum score is 19 for 5 students or $5,6 \%$ of the entire respondents and the sum of the most frequently score in the data set (Modus) on test score 13 is 14 students or $15,6 \%$ from the sum of the entire respondents.

The total number of respondents are 90, mean is 13,3 and standard deviation score is 3,157 . The standard deviation forms a normal curve. The curve is sharp and is called leptocurtic with kurtosis $-0,739$ and skewness - 
0,039 shows negative distribution or the left tail is a little bit longer although both tails look in the same line.

\section{Data of Parents' Role}

Parent's Role statistic is known from 90 respondents with the minimum score is 57 and the maximum score is 113. In addition, mean (average of all scores in the data set) is 86,878 , median (score at centre of distribution) is 86,800 and mode (most frequently obtained score in the data set) is 88 .

The minimum score is 57 for 1 student or $1,1 \%$ of 90 respondents and the maximum score is 113 for 1 student or $1,1 \%$ of the entire respondents. The sum of the most frequently score (Modus) is on score 88 for 6 students or $6,7 \%$ from the entire respondents.

A total number of respondents are 90 , mean is 86,878 , standard deviation is 12,035 . The standard deviation forms a normal curve which is quite sharp called as leptocurtic with kurtosis score $-0,247$. The curve is on the negative position or the curve tail is positioned on the left of the normal curve with swekness 0,095 .

\section{Data of English Achievement}

It is stated that English Achievement statistic is known from 90 respondents with minimum score is 65 and the maximum score is 95 . Meanwhile the average of all scores in the data set (Mean) is 80,678, median(score at centre of distribution) is 81,57 and mode (most frequently obtained score in the data set) is 90 .

It can be concluded that English Achievemnt score is good enough. In addition, standard deviation is 6,965 and variance is 48,513 . Minimum score is 65 for 3 students or $3,3 \%$ from the entire respondents and the maximum score is 95 for 2 students or 2,2\% from the entirer respondents. Modus is placed on score 90 for 10 students or $11,1 \%$ from the entire respondents.

A total number of respondents are 90, mean is 80,68 and standard deviation is 6,965 . The standard deviation forms a normal curve shape a quite sharp curve named leptocurtic with kurtosis -0,444 and skewness 0,304 forms negative distribution or the left tail curve is longer than the right one although it form a balance.

\section{Requirement Tests for the Data Normality Test}

Tests of normality for linguistic intelligence variable according Kolmogorov-Smirnov (K-S liliefors) has index 0,091, df (degree of freedom) 90 and significance 0,066. Significant index got from Kolmogorov-Smirnov is $\mathrm{P}>0,05$, so $\mathrm{H}_{\mathrm{o}}$ is accepted. In the other word, linguistic intelligence score is normal.

There is a straight line from down left to up right and also surrounding the straight line. There are quadrangular signs following it. If the signs of the score position spreading around the line, it points out that the score spreading for variable is normal (Nurgiantoro dkk, 2009:119). From the picture, it can be drawn that the position of the scores are around the line. As result, the score spreading for linguistic intelligence variable tested by the normality plot with tests is normal.

Meanwhile, tests of normality according to table 4.5 for parent's role variable based on Kolmogorov-Smirnov (K-S liliefors) has index 0,088, df ( degree of freedom) 90 and signficance 0,081 . Therefore, significance got from Kolmogorov-Smirnov is $\mathrm{P}>0,05$ so $\mathrm{H}_{0}$ is accepted. In the other word, parent's role variable score is normal.

There is a straight line from down left to up right and also surrounding the straight line. There are quadrangular 
signs following it. If the signs of the score position spreading around the line, it points out that the score spreading for the variable is noraml (Nurgiantoro dkk, 2009: 119). From the picture, it can be drawn that the position of the score are around the line. As a result, the score spreading for parent's role variable tested by normality plot with tests is normal.

\section{Linearity Test}

The linearity test of the regression can be used by calculating $F$ (significance probability level) then determining null hypothesis $\left(\mathrm{H}_{0}\right)$. If $\mathrm{F}$ $(\mathrm{Sig}=\ldots)$ is lower then $\mathrm{P}(0,05)$, as a result, the regression line of related data is linear. In the contrary, if $\mathrm{F}(\mathrm{Sig}=\ldots)$ is higher than $\mathrm{P}(0,05)$, the regression line is not linear. Therefore, the consequence is the data should be analyzed by non linear regression.

Based on Anova test, $\mathrm{F}$ is 54,868 with significance probability level is 0,000 (Sign=0,000). Sig 0,000 is lower than $0,05(0,000<0,05)$, therefore to predict the influence of linguistic intelligence toward English achievement out of 3 schools in Depok, the regression formulation can be used to analyze it. In other word, the data can be analyzed by using linear regression analysis.

Based on Anova test of Parent'srole and English Achievement, $\mathrm{F}$ is 54,868 with significance probability level is 0,000 ( $\mathrm{Sign}=0,000)$. Sig 0,000 is lower than $0,05(0,000<0,05)$, therefore to predict the influence of parent's role toward English achievement out of 3 schools in Depok, the regression formulation can be used to analyze it. In other word, the data can be analyzed by using linear regression analysis.
Testing of Hypotheses

The Influences of Linguistic Intelligence $\left(X_{1}\right)$ and Parent's Role $\left(\mathrm{X}_{2}\right)$ towards English Achievement (Y)

$\mathrm{H}_{0}: \beta_{1}=\beta_{2}=0$

$\mathrm{H}_{1}: \beta_{1} \neq \beta_{2} \neq 0$

Note:

$\mathrm{H}_{0}$ : There are no any positive and significant influences of linguistic intelligence and parent's tole towards English achievement.

$\mathrm{H}_{1}$ : There are positive and significant influences of linguistic intelligence and parent's role towards English achievement.

The relationship between linguistic intelligence $\left(\mathrm{X}_{1}\right)$ and Parent's Role $\left(\mathrm{X}_{2}\right)$ towards English Achievement (Y) which is counted with correlation coeficient is 0,742 or $\left(\mathrm{R}_{\mathrm{y} 12}=0,742\right)$. It shows that there is a strong relationship. Meanwhile linguistic intelligence and parent's role variables contribute to English achievement variable is $\mathrm{R}^{2} \mathrm{X}$ $100 \%$ or $(0,742)^{2} \times 100 \%=55,1 \%$ and the rest is $44,9 \%$ determined by the other factors.

Meanwhile to test hypotheses through regression analysis got the calculation which can be seen on table 4.9. It gets the regression line equality which representate the influence of linguistic intelligence and parent's role towards English achievement formulated in the following:

$$
\begin{aligned}
& Y=44,931+1,050 X_{1}+0,251 \\
& X_{2}
\end{aligned}
$$

Meanwhile test of significance for regression line above counted through considering the result on table 4.9. The criteria of the regression significance is "if $\mathrm{sig}<0,05$ so $\mathrm{H}_{0}$ is rejected" or "if $\mathrm{F}_{\text {observed }}>\mathrm{F}_{\text {table }}$ so $\mathrm{H}_{0}$ is 
rejected" wghich mean that regression coeficient is significant or in the other word there are positive and significant influences. Sig score is the number listed in the column of sig in table 4.9. $\mathrm{F}_{\text {observed }}$ is the number listed in the column $\mathrm{F}$ in table 4.9 meanwhile $\mathrm{F}_{\text {table }}$ score is the score of table distribution of $\mathrm{F}$ for the level $5 \%$ with $\mathrm{k}=2$ and $\mathrm{n}-\mathrm{k}-1$ $=90-2-1=87$ where $\mathrm{n}$ is the number of respondents and the number of independent variable.

Data shows that $\operatorname{sig}=0,000$ and $\mathrm{F}_{\text {observed }}=53,389$ meanwhile $\mathrm{F}_{\text {table }}$ $(0,05)(2,87)=3,103$ (the result of interpolation for $\mathrm{F}_{\text {table }}$ score). Due to sig score $<0,05$ and $F_{\text {counted }}>F_{\text {table }}$ so $\mathrm{H}_{0}$ is rejected which means the regression coeficient is significant. In the other word, there are positive and significant influences of linguistic intelligence and parent's role towards English achievement.

From correlation and regression tests above, it can be concluded that there are positive and significant influence between linguistic intelligence and parent's role towards English achievement.

\section{The Influences of Linguistic Intelligence $\left(\mathrm{X}_{1}\right)$ towards English Achievement (Y)}

$$
\begin{aligned}
& \mathrm{H}_{0}: \beta_{\mathrm{y} 1}=0 \\
& \mathrm{H}_{1}:{ }_{\mathrm{y} 1} \neq 0
\end{aligned}
$$

Note:

$\begin{aligned} \mathrm{H}_{0} & \text { : There is no any positive and } \\ & \text { significant influences of } \\ \text { linguistic intelligence } & \text { English } \\ \text { towards } & \text { achievement. } \\ \mathrm{H}_{1} \quad & \begin{array}{l}\text { : There is positive and } \\ \text { significant influences of } \\ \text { linguistic intelligence } \\ \text { towards } \\ \text { achievement. }\end{array}\end{aligned}$

Testing the hypothesis is done through analyzing calculation of SPSS version 17 on table 4.10 with the criteria of regression significant is "if $t_{\text {observed }}>$ $\mathrm{t}_{\text {table }}$ so $\mathrm{H}_{0}$ is rejected" or "if sig $<0,05$ so $\mathrm{H}_{0}$ is rejected" which means that there is significant influence of linguistic intelligence towards English achievement. The score for $t_{\text {observed }}$ is listed on column $t$ for linguistic intelligence meanwhile $t_{\text {table }}$ is listed on table distribution of $\mathrm{t}$ with the level $5 \%$ and $\mathrm{df}=\mathrm{n}-2=90-2=88$ where $\mathrm{n}$ is the number of respondents.

According to table 4.10, it shows that sig score is 0,000 and $t_{\text {observed }}$ is 6,250 meanwhile $t_{\text {table }}(0,05,88)=1,990$ (the result of interpolation $t_{\text {table }}$ score). Due to Sig score $<0,05$ and $t_{\text {observed }}>$ $t_{\text {table }}$ so $\mathrm{H}_{0}$ is rejected which means that there is positive and significant influence of linguistic intelligence towards English achievement.

From the tests of correlation and regression above, it can be concluede that there is positive and significant influence of linguistic intelligence towards English achievement.

The Influence of Parent's Role $\left(\mathrm{X}_{2}\right)$ towards English Achievement (Y)

$$
\begin{aligned}
& \mathrm{H}_{0}: \beta_{\mathrm{y} 2}=0 \\
& \mathrm{H}_{1}:{ }_{\mathrm{y} 2} \neq 0
\end{aligned}
$$

Note:

$\mathrm{H}_{0}$ : There is no any positive and significant influences of parent's role towards English achievement.

$\mathrm{H}_{1}$ : There is positive and significant influences of parent's role towards English achievement.

Testing the hypothesis is done through analyzing the calculation of SPSS version 17 on table 4.10 with the criteria of regression significant is "if 
$t_{\text {observed }}>t_{\text {table }}$ so $\mathrm{H}_{0}$ is rejected" or "if sig $<0,05$ so $\mathrm{H}_{0}$ is rejected" which means that there is significant influence of parent's role towards English achievement. The score for $t_{\text {observed }}$ is listed on column $t$ for parent's role meanwhile $t_{\text {table }}$ is listed on table distribution of $\mathrm{t}$ with the level $5 \%$ and $\mathrm{df}=\mathrm{n}-2=90-2=88$ where $\mathrm{n}$ is the number of respondents.

According to table 4.10, it shows that sig score is 0,000 and $t_{\text {observed }}$ is 5,688 meanwhile $t_{\text {table }}(0,05,88)=1,990$ (the result of interpolation $t_{\text {table }}$ score). Due to Sig score $<0,05$ and $t_{\text {observed }}>$ $t_{\text {table }}$ so $\mathrm{H}_{0}$ is rejected which means that there is positive and significant influence of parent's role towards English achievement.

From the tests of correlation and regression above, it can be concluede that there is positive and significant influence of parent's role towards English achievement.

\section{The Influences of Linguistic} Intelligence $\left(X_{1}\right)$ and Parent's Role $\left(X_{2}\right)$ towards English Achievement (Y)

On the basis of calculated data, indicating that both linguistic intelligence and parent's role contribute to English achievement. Dealing with linguistic intelligence variable which use worksheet to test either subskill in English or to test communication skill, it is important to note that English achievement can be achieved and increase by sharpening these two dimension of linguistic intelligence.

Nevertheless,

English

achievement is not only affected by this variable but also how parents show their attention to the children by giving loveship, discipline and responsibility, facility and financial support to the students. Those are proven by correlation coeficient which get 0,742 or $\mathrm{R}_{\mathrm{y} 12}=0,742$. This shows that there are strong influences among them. Futhermore, linguistic intelligence and parent's role contribute to English achievevement variable is $\mathrm{R}^{2} \mathrm{X} 100 \%$ or $(0,742)^{2} \times 100 \%=55,1 \%$ and the rest $44,9 \%$ is determined by another factor. The equality can be seen through $\mathrm{Y}=$ $44,931+1,050 \mathrm{X}_{1}+0,251 \mathrm{X}_{2}$

The Influence of Linguistic Intelligence $\left(\mathrm{X}_{1}\right)$ towards English Achievement (Y)

Observing from the result of data analysis, it can be seen that $\mathrm{t}_{\text {observed }}=$ 6,250 and $t_{\text {table }}=1,990$. It means that $t_{\text {observed }}>t_{\text {table }}$ and sig score is 0,000 which means sig $<0,05$. Therefore, $\mathrm{H}_{0}$ is rejected and it can be concluded that there is a positive and strong influence of linguistic intelligence toward English achievement.

From the research toward three schools namely SMA Tugu Ibu, SMA Sejahtera and SMA Yapan Indonesia, there is important information that increasing vocabulary, grammar and pronunciation ability and increasing communication subskill which consist of reading, writing, listening and speaking are able to make a good and satisfied achievement in English subject.

The Influence of Parent's Role $\left(\mathrm{X}_{2}\right)$ towards English Achievement (Y)

Based on the result of data analysis, it can be seen that $t_{\text {observed }}=$ 5,688 and $t_{\text {table }}=1,990$. It means that $\mathrm{t}_{\text {observed }}>\mathrm{t}_{\text {table }}$ and sig score is 0,000 which means sig $<0,05$. Therefore, $\mathrm{H}_{0}$ is rejected and it can be concluded that there is a positive and strong influence of parent's role toward English achievement. From the questionnaire, it indicates that the attention from their parents in the form of loveship, managing responsibility and disipline, 
giving facility and financial support make the students feel comfortable to learn and study in order to get satisfied achievement through getting a good score in English.

\section{CONCLUSION}

On the basis of computerized processing and data analysis, some following conclusions can be drawn.

1. There are significant influences of linguistic intelligence $\left(\mathrm{X}_{1}\right)$ and parent's role $\left(\mathrm{X}_{2}\right)$ towards English achievement $(\mathrm{Y})$. It can be seen from the result of the multiple regression where the multiple coefficient (R) is 0,742 . It is obtained that $\mathrm{F}_{\text {observed }}$ is 53,389 and $F_{\text {table }}$ is 2,735. Since $\mathrm{F}_{\text {observed }}$ is higher than $\mathrm{F}_{\text {table }}(53,389>$ $2,735)$ and sig $0,000<0,05$ therefore $\mathrm{H}_{0}$ is rejected. In addition, the contribution is $55,1 \%$.

2. There is a sinificant influence of linguistic intelligence $\left(\mathrm{X}_{1}\right)$ towards English achievement (Y). It is obtained that $\mathrm{t}_{\text {observed }}$ is higher than $t_{\text {table }}(6,250>1,990)$ with Sig score is lower than significance grade $(0,000$ $<0,05)$. It indicates that there is significant influence.

3. There is a significant influence of parent's role $\left(\mathrm{X}_{2}\right)$ towards English achievement $(\mathrm{Y})$. It is obtained that $\mathrm{t}_{\text {observed }}$ is higher than $\mathrm{t}_{\text {table }}(5,688>$ 1,990) with Sig score is lower than significance grade $(0,000<0,05)$. It indicates that there is significant influence.

\section{REFERENCES}

Astuti, N. M. (2008). Hubungan antara Minat, Self-Efficacy, Inteligensi dengan Prestasi Belajar Bahasa Inggris pada Peserta Didik Kelas $X$, SMA Negeri 37 Jakarta. Jakarta: Tesis Pascasarjana UPI YAI.

Aunurrahman. (2009). Belajar dan Pembelajaran. Bandung: Alfabeta.

Dahar, R. W. (2011). Teori-teori Belajar dan Pembelajaran. Jakarta: Erlangga.

Prawira, P. A. (2012). Psikologi Pendidikan: dalam Perspektif Baru. Jogjakarta: Ar-Ruzz Media.

Richard, J., \& Rodgers, T. (2001). Approaches and Methods in Language Teaching. New York: Cambridge University Press.

Sadirman. (2001). Interaksi dan Motivasi Mengajar. Jakarta: Rajawali Pers.

Slameto. (2003). Belajar dan FaktorFaktor yang Mempengaruhinya. Jakarta: Rineka Cita.

Syah, M. (2000). Psikologi Pendidikan Suatu pengantar Baru. Bandung: Remaja Rosdakarya.

Tohirin, M. S. (2005). Psikologi Pembelajaran Agama Islam. Jakarta: Raja Grafindo Persada.

Winkel, W. S. (1996). Psikologi Pendidikan dan Evaluasi Belajar. Jakarta: Gramedia. 